Arkadiusz Domagała

ORCID: 0000-0003-4974-7618

Uniwersytet Wrocławski

\title{
Powstanie Powszechnej deklaracji praw człowieka. Kontrowersje dotyczące autorstwa i podziału ról w przygotowywaniu i przyjęciu tekstu dokumentu
}

\author{
DOI: 10.19195/1643-0328.25.8
}

Słowa kluczowe: ochrona prawa człowieka, Powszechna deklaracja praw człowieka, twórcy Powszechnej deklaracji praw człowieka, Komisja Praw Człowieka ONZ

\section{Wprowadzenie}

Powszechna deklaracja praw człowieka uznawana jest za przełomowy dokument w historii międzynarodowych praw człowieka. Nie ulegało wątpliwości już w trakcie jej powstawania, że mimo niewiążącego charakteru będzie wpływała na praktykę legislacyjną i zachowania państw na arenie międzynarodowej. Waga polityczna dokumentu przez wiele lat usuwała na drugi plan pytania o wkład poszczególnych członków Komisji Praw Człowieka i specjalnego komitetu redakcyjnego w przygotowanie Powszechnej deklaracji praw człowieka. Kwestia jej autorstwa pojawiała się w dyskursie międzynarodowym co najmniej dwukrotnie - w przededniu otrzymania przez René Samuela Cassina Pokojowej Nagrody Nobla w 1968 r. oraz dwadzieścia lat później, gdy na jaw wyszło o wiele większe, niż wcześniej zakładano, zaangażowanie funkcjonariuszy Sekretariatu Generalnego ONZ w kształtowanie dokumentu. Proces tworzenia Deklaracji z formalnego punktu widzenia jest dobrze znany i zaprezentowany w literaturze przedmiotu, więc wątek ten zostanie potraktowany marginalnie ${ }^{1}$. Niniejszy artykuł prezentuje nie tyle perspektywę państw, które formalnie przyjmowały dokument, ile jednostek, które zaangażowane były w tworzenie dokumentu. W ocenie udziału poszczególnych członków Komisji Praw Człowieka

1 Zob. m.in. J. Morsink, Universal Declaration of Human Rights. Origins, Drafting, and Intent, Philadelphia 1999; S.M. Darraj, Universal Declaration of Human Rights, New York 2010; G. Johnson, J. Symonides, Universal Declaration of Human Rights: A History of Its Creation and Implementation, 1948-1998, Paris 1998; M.A. Glendon, World Made New: Eleanor Roosevelt and the Universal Declaration of Human Rights, New York 2001. 
w tworzeniu i przyjęciu Powszechnej deklaracji praw człowieka szczególną rolę miały archiwalne dokumenty (protokoły, stenogramy i nagrania) z posiedzeń Komisji Praw Człowieka, Rady Ekonomiczno-Społecznej, Trzeciego Komitetu Zgromadzenia Ogólnego oraz komitetu przygotowującego tekst dokumentu (drafting committee) $)^{2}$.

\section{Kolektywny charakter prac nad dokumentem}

Nie ulega wątpliwości, że Powszechna deklaracja praw człowieka była dziełem kolektywnym. W jej powstaniu udział miały dziesiątki osób, które możemy uszeregować następująco: a) członkowie tzw. małego komitetu redakcyjnego Komisji Praw Człowieka wraz z Johnem Petersem Humphreyem oraz dokooptowanym później René Cassinem (jako członkiem tzw. drugiego komitetu redakcyjnego); b) pozostali członkowie komitetu redakcyjnego oraz członkowie Komisji Praw Człowieka; c) przedstawiciele państw w tzw. Trzecim Komitecie Zgromadzenia Ogólnego; d) członkowie komitetów doradczych (głównie Komitetu do spraw Teoretycznych Podstaw Praw Człowieka). W zainicjowaniu i przyjęciu Deklaracji uczestniczyły ponadto organy ONZ (Rada Gospodarczo-Społeczna, Zgromadzenie Ogólne), których przedstawiciele mieli jednak ograniczony wpływ na treść dokumentu.

Jednym z głównych założeń niniejszego artykułu jest stwierdzenie, że nawet w dziele mającym wielu autorów można wyróżnić jednostki nadające ton pracom i w konkretny sposób decydujące o treści dokumentu. Zagadnienie udziału określonych jednostek w procesie tworzenia Deklaracji zostanie poddane krótkiej analizie wraz z poszukiwaniem odpowiedzi na pytanie, jakie role można przypisać grupie osób uznawanych za autorów Powszechnej deklaracji praw człowieka (a tym samym — jak można zróżnicować ową grupę). Wątkiem pobocznym w pracy jest próba określenia, czy elementy subiektywistyczne/poglądy jednostek wpływały na treść dokumentu (zakres i kształt praw, źródła praw itp.).

Powstanie dokumentu grupującego prawa i wolności jednostek miało być pierwszym poważnym zadaniem Komisji Praw Człowieka ${ }^{3}$. Jeszcze przed jej powstaniem utworzono specjalny komitet (nuclear committee) określający strukturę i przygotowujący przyszłe działania Komisji jako organu pomocniczego Rady Gospodarczo-Społecznej. Na pierwszym spotkaniu 18-osobowej Komisji (w jej skład wchodzili przedstawiciele Wielkiej Piątki oraz Australia, Belgia, Białoruska Republika Socjalistyczna, Chile, Egipt, Indie, Iran, Liban, Panama, Filipiny, Jugosławia, Ukraińska Republika Socjalistyczna, Urugwaj)

${ }^{2}$ Powyższe dokumenty znajdują się w zasobach biblioteki Narodów Zjednoczonych Daga Hammarskjölda.Zob. m.in.: http://research.un.org/en/undhr/ga/thirdcommittee, http://research.un.org/en/undhr/ draftingcommittee/1, http://research.un.org/en/undhr/draftingcommittee/2, http://research.un.org/en/ undhr/chr/1, http://research.un.org/en/undhr/ecosoc/2, http://research.un.org/en/undhr/ecosoc/2 (dostęp: 27.12.2015).

${ }^{3} \mathrm{Na}$ temat Komisji Praw Człowieka zob. m.in. H. Tolley, The U. N. Commission on Human Rights, Boulder-London 1987; R. Freedman, The United Nations Human Rights Council. A Critique and Early Assessment, New York 2013; A.F. Bayefsky, The UN Human Rights Treaty System, Hague 2001. 
w styczniu 1947 r. podjęto decyzję o wyodrębnieniu grupy osób odpowiedzialnych za przygotowanie projektu Karty praw człowieka. Decyzja ta wynikała z przekonania, że niezwykle zróżnicowana i dość liczna Komisja nie będzie w stanie przygotować koherentnego dokumentu. Warto również zauważyć, że skład pierwszej Komisji był dość charakterystyczny, bo oddający specyfikę i atmosferę czasu.

Pierwszy etap prac Komisji przypadał na okres po II wojnie światowej (więc jej członkowie mieli w pamięci powszechne naruszenia praw człowieka w latach 1937-1945), ale jeszcze przed zimnowojenną konfrontacją, toteż była ona bardziej gronem intelektualistów i aktywistów praw człowieka niż typowych przedstawicieli państw realizujących partykularny narodowy interes. Przewodniczącym Komisji została Eleanor Roosevelt ze Stanów Zjednoczonych, jej zastępcą Peng-chun Chang z Chin, a sprawozdawcą Charles Malik z Libanu - właśnie ta trójka miała być odpowiedzialna - korzystając z pomocy Sekretariatu Generalnego ONZ - za przygotowanie projektu Deklaracji praw człowieka ${ }^{4}$.

\section{Eleanor Roosevelt}

Eleanor Roosevelt (1884-1962) była nadzwyczaj sprawnym i zręcznym przewodniczącym Komisji Praw Człowieka i komitetu redakcyjnego, a jej zaangażowanie i umiejętność budowania relacji w złożonym zespole wybitnie wpłynęły na przyjęcie projektu, a następnie samej Deklaracji. Nie bez znaczenia był jej wizerunek jako byłej Pierwszej Damy (była żoną zmarłego w 1945 r. Franklina D. Roosevelta), choć początkowo jej kompetencje jako członka amerykańskiej delegacji w ONZ traktowano z przymrużeniem oka ${ }^{5}$. Eleanor Roosevelt potrafiła dzięki niezwykle inteligentnemu i profesjonalnemu podejściu do ochrony praw człowieka powściągać obstrukcyjne i antywolnościowe propozycje państw rodzącego się bloku komunistycznego ${ }^{6}$. Kiedy doszło do głosowania nad objęciem funkcji przewodniczącego Komisji Praw Człowieka, Eleanor Roosevelt była naturalnym kandydatem, a wyboru dokonano jednomyślnie. Mimo iż reprezentantka USA nie była politykiem, a raczej aktywistką, dysponowała atrybutami, które dawały jej nieuchwytną przewagę w trakcie obrad: była opanowana, zdeterminowana, błyskotliwa, nie dawała się prowokować i nie zrażała się porażkami ${ }^{7}$. Roosevelt nie była również znawcą prawa międzynarodowego, stąd musiała polegać często na zaangażowaniu i wiedzy innych członków komitetu redakcyjnego, a jej atutem była umiejętność pozyskiwania ludzi, także tych o odmiennych poglądach, dla idei praw człowieka. Widoczne było to m.in. $\mathrm{w}$ wyborze tzw. małego komitetu redakcyjnego, kiedy to $\mathrm{w}$ trakcie inicjowanych przez Eleanor Roosevelt na wpół prywatnych spotkań z Malikiem, Changiem i Humphreyem

${ }^{4}$ M.A. Glendon, op. cit., s. 32-44.

5 E. Roosevelt, On My Own, New York 1958, s. 44; S. McFarland, The Universal Declaration of Human Rights: A tribute to its architects, „Public Integrity” 19, 2017, s. 10.

${ }^{6}$ J. Sears, Eleanor Roosevelt and the Universal Declaration of Human Rights, s. 4, http://www.fdrlibrary. marist.edu/library/pdfs/sears.pdf (dostęp: 19.12.2015). Zob. także E. Roosevelt, Human rights and human freedom: The American perspective, „New York Times Magazine” 24 marca 1946, s. 21.

7 J. Sears, op. cit., s. 5-6. 
wykuwały się koncepcyjne podstawy Deklaracji ${ }^{8}$. Jej spojrzenie na prawa człowieka było bardzo szerokie, co można powiązać także z aktywnością polityczną jej męża - prospołecznymi rozwiązaniami Nowego Ładu oraz programem wprowadzenia praw drugiej generacji (Second Bill of Rights), a także z jej wyczuleniem na naruszenia praw człowieka, ludzką niedolę i osobistym zaangażowaniem, zwłaszcza w trakcie II wojny światowej ${ }^{9}$. Sugerować to mogło akceptację (a co najmniej zrozumienie) Roosevelt dla włączenia do Deklaracji praw ekonomiczno-społecznych. Nie ulega wątpliwości, że wkład merytoryczny E. Roosevelt w budowanie Powszechnej deklaracji praw człowieka nie był znaczny, a bez wątpienia daleko mniejszy niż wymienionych w dalszej części artykułu członków organów przygotowujących treść dokumentu. Jak jednak zauważał Charles Malik, bez jej patronatu i charyzmy łagodzącej opinie członków komitetu redakcyjnego przygotowanie Powszechnej deklaracji nie byłoby możliwe ${ }^{10}$.

\section{Charles Malik}

Charles Habib Malik (1906-1987), obok Changa, uchodził w gronie Komisji Praw Człowieka za człowieka wybitnego, o ponadprzeciętnym intelekcie. Był nie tylko dyplomatą, ale także matematykiem, fizykiem, a nade wszystko filozofem. Pozostawał pod wpływem egzystencjalizmu Martina Heideggera, którego był uczniem, a w kwestii praw człowieka uchodził za gorącego zwolennika tzw. praw naturalnych. Podobnie jak Chang, naciskał na pozostałych członków komitetu redakcyjnego i Komisji, aby Deklaracja była wyrazem nie tylko myśli zachodniej, ale i doświadczeń innych cywilizacji na temat natury człowieka i przysługujących mu praw ${ }^{11}$. Malik, podobnie jak Roosevelt, wierzył, że Deklaracja, mimo swojego niewiążącego charakteru, będzie potężnym orężem dla zwolenników praw człowieka na wszystkich kontynentach i poprzez swoją siłę moralną wpłynie na praktykę legislacyjną państw oraz wzmocni grupy obrońców praw człowieka na świecie.

Najistotniejszy wkład Malika w tworzenie dokumentu nie odnosi się jednak do jego roli w komitecie redakcyjnym, ale w Społecznym, Kulturalnym i Humanitarnym Komitecie Zgromadzenia Ogólnego ONZ. Malik był przewodniczącym tego ciała (nazywanego potocznie Trzecim Komitetem), pełniąc w ten sposób nieformalną rolę strażnika projektu dokumentu, jego treści i ducha. Bez wątpienia jego zaangażowanie wpłynęło na przyjęcie Powszechnej deklaracji w trakcie sesji Zgromadzenia Ogólnego w 1948 r., co miało kolosalne znaczenie w obliczu zaostrzającej się sytuacji międzynarodowej ${ }^{12}$.

8 Więcej na ten temat: E. Roosevelt, The Autobiography of Eleanor Roosevelt, New York 1992, s. 314-323.

9 Zob. m.in. F.D. Roosevelt, The Economic Bill of Rights, [w:] The Public Papers \& Addresses of Franklin D. Roosevelt, t. 13, red. S. Rosenman, New York 1950, s. 40-42.

10 J. Morsink, op. cit., s. 32.

11 Zob. m.in. G. Mitoma, Charles H. Malik and human rights: notes on a biography, „Personal Narrative \& Political Discourse" 33, 2010, s. 222-223.

12 W trakcie 71 dni (od 27 września do 7 grudnia 1948) odbyło się aż 85 spotkań Trzeciego Komitetu. Malik m.in. zarządzał nocne sesje Komitetu oraz proponował maksymalnie trzyminutowe wystąpienia, których czas skrupulatnie nadzorował przy pomocy stopera. Zob. M.A. Glendon, op. cit., s. 153. 
Malik jako przewodniczący musiał zmierzyć się z próbami obstrukcji - w trakcie obrad w Trzecim Komitecie debatowano niemalże nad każdym słowem Deklaracji, zgłoszono prawie 170 poprawek, z których wiele znalazło uznanie Komitetu. Malikowi przypisuje się m.in. rozszerzenie prawa dotyczącego wyznania (wskazania, że prawo to ma wymiar prywatny, publiczny, indywidualny, kolektywny oraz że obejmuje prawo do konwersji) i określenie ostatecznego kształtu artykułu 28 (Malik uzasadniał, że to ONZ jest wyrazem porządku międzynarodowego i jej odpowiedzialnością jest zapewnianie implementacji praw zawartych w Deklaracji $)^{13}$. Malik jest ponadto głównym autorem preambuły zatwierdzonej przez Trzeci Komitet. Jako gorliwy chrześcijanin próbował „przemycić" odwołanie do Boga - w artykule 16 dotyczącym małżeństwa i rodziny proponował dodać „jako ufundowanych przez Stwórcę", ale jego sugestia została odrzucona w trakcie prac Komisji Praw Człowieka ${ }^{14}$. Niemniej jednak warto zauważyć, że Malik zgadzał się co do zasady, by kwestię godności i uniwersalizmu odseparować od kategorii religijnych.

\section{Peng-chun Chang}

Peng-chun Chang (1893-1957), wiceprzewodniczący Komisji Praw Człowieka, mimo iż wykształcony w Stanach Zjednoczonych, pozostał wierny chińskiej tradycji i myśli filozoficznej (zwłaszcza konfucjanizmowi). Nie oznaczało to jednak w Komisji i komitecie redakcyjnym permanentnych sporów między zachodnim a dalekowschodnim rozumieniem praw człowieka, gdyż Chang prezentował bardzo konsensualne i konstruktywne podejście w budowie dokumentu, zwracając uwagę (częściowo opozycyjnie względem Malika) m.in. na konieczność ekskluzji kategorii Boga jako źródła godności i praw naturalnych ${ }^{15}$. Stanowisko to zdołano przeforsować głównie dzięki postawie Changa. Inną kwestią, w której zauważyć można wkład Changa, była forsowana podczas obrad Trzeciego Komitetu równość praw wszystkich ludzi i uniwersalizm praw człowieka. W trakcie finalnych prac redakcyjnych jego stanowisko wspierał René Cassin - ich współpraca widoczna była także w trakcie komponowania preambuły dokumentu ${ }^{16}$. Powyższe wnioski znajdują odzwierciedlenie w analizie interwencji/przemówień Changa w trakcie prac

13 Zob. m.in. UN Doc. A/C.3/SC.4/16, UN Doc. A/C.3/365, UN Doc. A/C.3/279, UN Doc. A/C.3/262, UN Doc. A/C.3/235. Zob. także J. Morsink, op. cit., s. 231.

14 S. McFarland, op. cit., s. 116.

15 Kategorie godności i praw naturalnych jako podstawy uniwersalnych praw człowieka były bliskie szczególnie Jacques'owi Maritainowi, członkowi Komitetowi UNESCO do spraw Teoretycznych Podstaw Praw Człowieka. Zob. m.in. M. Vatter, Politico-theological foundations of the universal human rights: The case of Maritain, „Social Research” 80, 2013, nr 1, s. 233-257. Zob. także debata w Trzecim Komitecie UN Doc. A/C.3/SR.95 oraz A/C.3/SR.98.

16 F. Krumbein, P.C. Chang - Chinese father of human rights, „Journal of Human Rights” 15, 2014, s. 339. 
nad Deklaracją - w największym stopniu interesowały go kwestie filozoficznego tła dokumentu, jego struktury, a także preambuły i praw zasadniczych ${ }^{17}$.

Chang wraz z Malikiem byli siłą napędową komitetu redakcyjnego w sensie koncepcyjnym. Często określano ich jako najwybitniejszych intelektualistów, którzy kiedykolwiek zasiadali w Komisji Praw Człowieka ${ }^{18}$. Mimo iż w kwestiach filozoficznych pozostawali zazwyczaj w sporze, łączyło ich szczere podejście do promowania i ochrony międzynarodowych praw człowieka. Zaryzykować można twierdzenie, że pierwszy i drugi projekt dokumentu były pokłosiem filozoficznego dyskursu między Malikiem a Changiem. W trakcie finalnej prezentacji projektu Deklaracji przed Zgromadzeniem Ogólnym Malik podziękował za współpracę właśnie Changowi - za to, że „nigdy nie ustawał w poszerzaniu naszej perspektywy" o prawach człowieka ${ }^{19}$.

\section{John Humphrey}

John Humphrey (1905-1995) był kanadyjskim profesorem prawa międzynarodowego, a od 1946 r. także dyrektorem Departamentu Praw Człowieka w Sekretariacie Generalnym ONZ. Niezwykle doświadczony życiowo (utrata rodziców i kalectwo w dzieciństwie, nauka w represywnej szkole z internatem), otwarty na szeroko rozumiane prawa człowieka, został nieformalnym członkiem tzw. małego komitetu redakcyjnego przygotowującego projekt Powszechnej deklaracji praw człowieka.

W trakcie pierwszego spotkania z E. Roosevelt, C. Malikiem i P. Changiem zadecydowano, że to właśnie Humphrey przygotuje materiały potrzebne do realizacji zadania przedłożonego komitetowi przez Komisję Praw Człowieka ${ }^{20}$. Humphrey podszedł do niego niezwykle poważnie. Wraz ze swoim zespołem prześledził szereg dotychczasowych rozwiązań, powstałych na gruncie różnorakich kultur, mających na celu ochronę praw człowieka (konstytucji, projektów podobnych deklaracji, a także postulatów rządów i organizacji pozarządowych) ${ }^{21}$. Efektem tego było przygotowanie 400 -stronicowego opracowania będącego komentarzem do skompletowanych dokumentów, a przede wszystkim projekt Deklaracji praw człowieka składający się z 48 artykułów. Projekt ten został

17 Ibidem, s. 332-333. Tam też więcej na temat wkładu P. Changa w tworzenie oraz implementowanie Powszechnej deklaracji praw człowieka.

$18 \mathrm{~J}$. Humphrey, The Universal Declaration of Human Rights: Its History, Impact, and Juridical Character, [w:] Human Rights Thirty Years After the Universal Declaration, red. B.G. Ramcharan, Boston 1979, s. 23.

19 S. McFarland, op. cit., s. 118.

20 E. Roosevelt, On My Own..., s. 77. W prywatnych listach do siostry Humphrey podkreślał, że opracowując projekt, czuł się jak Thomas Jefferson (uznawany za twórcę Konstytucji USA).

21 W czym widać m.in. wpływ Changa i Malika. Jak przyznawał John Humphrey, szczególną rolę w jego pracy odegrały dwa dokumenty: projekt Amerykańskiej deklaracji praw i obowiązków człowieka oraz opracowanie na temat praw człowieka Instytutu Prawa Amerykańskiego (Statement of Essential Human Rights). Zob. J. Humphrey, Human Rights and the United Nations: A Great Adventure, New York 1984, s. 31-32. 
następnie przedłożony w czerwcu 1947 r. komitetowi redakcyjnemu składającemu się już jednak nie z trzech, ale ośmiu członków Komisji ${ }^{22}$.

Wkład Humphreya w przygotowanie Deklaracji długo pozostawał niedoszacowany. Przez wiele lat pokutował mit o jednym, zasadniczym autorze dokumentu, $\mathrm{z}$ upływem czasu wzmocniony przyznaniem Pokojowej Nagrody Nobla Cassinowi ${ }^{23}$. Udział Humphreya nie ograniczał się do stworzenia pierwszego projektu Deklaracji, ale przypisuje mu się także wskazanie na rolę praw społeczno-gospodarczych (m.in. prawo do pracy, wynagrodzenia, edukacji, odpoczynku, świadczeń socjalnych) jako przysługujących jednostce. Mimo iż uwypuklanie tychże było dość dalekie anglosaskiej tradycji polityczno-prawnej, Humphreyowi, a następnie Roosevelt udało się do nich przekonać Stany Zjednoczone i Wielką Brytanię ${ }^{24}$. Projektowi Humphreya brakowało pewnej spoistości i idei porządkującej tekst koncepcji, co jednak w niczym nie umniejsza jego roli w przygotowaniu dokumentu.

\section{René Cassin}

W trakcie prac komitetu redakcyjnego Francja (w osobie René Cassina), wspierana przez przedstawiciela ZSRR Władimira Koreckiego (Koretsky'ego), uznała poprzednią decyzję Komisji o wyznaczeniu tylko trzech osób mających opracowywać projekt Deklaracji za "godną pożałowania" 25 (mimo iż Cassin sam za tą decyzją głosował) i zaproponowała poszerzenie komitetu redakcyjnego. W skład powołanego tzw. dużego komitetu weszli dodatkowo Cassin, Korecki ${ }^{26}$, Hernan Santa Cruz (Chile), Charles Dukes (Wielka Brytania) i William Hodgson (Australia). Już w czerwcu 1947 r. Cassin zaproponował komitetowi przejrzenie dotychczasowego efektu prac i „,logiczne uporządkowanie” zawartych w projekcie artykułów. Szybko stworzono grupę roboczą, na której czele stanął przedstawiciel Francji, a efektem tych prac był kolejny, uznany za oficjalny, projekt Deklaracji ${ }^{27}$.

René Samuel Cassin (1887-1976) bardzo dobrze odnajdywał się w pracach komitetu redakcyjnego. Już w latach 40. XX w. uchodził za znamienitego znawcę prawa międzynarodowego, a na jego prohumanitarne poglądy bez wątpienia wpłynęły doświadczenia

22 Zob. UN Doc. E/CN.4/AC.1/3 (4 lipca 1947). Więcej na temat roli Humphreya zob. M.A. Glendon, John P. Humphrey and the drafting of the Universal Declaration of Human Rights, „Journal of the History of International Law" 2000, nr 2, s. 250-260.

23 S. Waltz, Reclaiming and rebuilding the history of the Universal Declaration of Human Rights, „Third World Quarterly" 23, 2002, nr 3, s. 441.

24 S. McFarland, op. cit., s. 113.

25 Cyt za: M.A. Glendon, John P. Humphrey..., s. 253.

26 W pracach komitetu ZSRR reprezentował głównie Aleksiej Pawłow, a później zastąpił go Aleksander Bogomołow.

27 UN Doc. E/CN.4/AC.1/W.2/Rev2. W dokumentach komitetu redakcyjnego wielokrotnie przedstawia się Cassina w sposób sugerujący, że jest autorem nowego projektu. 
Holocaustu (Cassin pochodził z rodziny żydowskiej). Do dziś uznawany jest za jednego $\mathrm{z}$ najznakomitszych francuskich prawników ${ }^{28}$.

Cassin po wstąpieniu do komitetu redakcyjnego odegrał zasadniczą rolę w przeformułowaniu projektu zaprezentowanego przez zespół Humphreya. Podkreśla się często jego umiejętności redakcyjne, pozwalające na przygotowanie złożonego aktu prawnego, utrzymanego w kontynentalnej (europejskiej) tradycji prawnej. Dokonując rewizji projektu Humphreya, Cassin, we współpracy z innymi członkami komitetu, dodał preambułę i zestaw zasad wskazujących na interpretację postanowień Karty, a także przeorganizował główne postanowienia projektu dokumentu ${ }^{29}$. Na początku projektu znajdowały się dwa zasadnicze artykuły określające podstawy i zasady stosowania praw, potem następowały artykuły odnoszące się do praw osobistych, dalej artykuły dotyczące praw politycznych i obywatelskich, a na końcu umieszczono prawa o charakterze ekonomicznym, społecznym i kulturalnym ${ }^{30}$.

Projekt Cassina składał się z 42 artykułów i zawierał zdecydowaną większość materiału przygotowanego przez Humphreya, co wskazywałoby jednoznacznie na projekt Sekretariatu jako pierwotny. Z analizy tekstów Sekretariatu i Cassina wynika, że przeszło trzy czwarte tekstu pokrywa się z sobą, a wedle Alana Johna Hobbinsa Cassin poprawił dotychczasowy projekt w ciągu weekendu i to nie samodzielnie, ale z pomocą Emile’a Girauda $\mathrm{z}$ departamentu Humphreya ${ }^{31}$. Niemniej jednak Cassin był kluczowym aktorem w trakcie dwóch z trzech sesji Komisji Praw Człowieka, zmierzającym zdecydowanie do zaakceptowana Deklaracji. Za najistotniejszą zmianę wprowadzoną przez Cassina można uznać zmianę nazwy dokumentu. Pierwotnie był on zatytułowany jako Międzynarodowa karta praw ludzi, co według Cassina wskazywało na międzypaństwowy charakter dokumentu. Przyjęcie określania „Powszechna” (Universal) miało sugerować jednoznacznie, że państwa nie nadają praw, gdyż te przynależą jednostkom na mocy ich istnienia i niezbywalnej godności ${ }^{32}$.

René Cassin często był i jest przedstawiany jako główny autor Powszechnej deklaracji praw człowieka ${ }^{33}$. W komitecie przygotowującym projekt odgrywał istotną rolę od drugiej połowy 1947 r., kiedy to przejął większość prac redaktorskich, a następnie wielokrotnie prezentował na forum publicznym organów ONZ dorobek prac komitetu i Komisji i tegoż dorobku silnie bronił. W latach kolejnych sam Cassin wskazywał na siebie jako projektodawcę Deklaracji, deprecjonując w ten sposób, być może nieświado-

${ }^{28}$ Cassin był m.in. prezesem Europejskiego Trybunału Praw Człowieka i przewodniczącym Komisji Praw Człowieka ONZ.

29 Preambuła przygotowana przez Cassina została odrzucona, a nad jej rewizją pracował przede wszystkim Malik. S. McFarland, op. cit., s. 115.

${ }^{30}$ Ibidem. Zob. także M.A. Glendon, World Made New..., s. 62-64.

31 A.J. Hobbins, René Cassin and the Daughter of Time: the first draft of the Universal Declaration of Human Rights, „Fontanus” 2, 1989, s. 12, http://digitool.Library.McGill.CA:80/R/-?func=dbin-jumpfull\&object_id=19018\&silo_library=GEN01 (dostęp: 25.01.2016). Zob. także M.A. Glendon, World Made New..., s. 271-280.

32 S. McFarland, op. cit., s. 117.

33 E. Hermon, The promotion of human rights: René Cassin's contribution to the promotion of peace, „Peace and Change” 16, 1991, nr 1, s. 3-21; S. Waltz, op. cit., s. 442. 
mie, rolę Johna Humphreya ${ }^{34}$. Tymczasem ze wspomnień uczestników opracowywania Deklaracji, dokumentów Komisji Praw Człowieka oraz jej komitetu, a przede wszystkim z odnalezionych w 1988 r. manuskryptów autorstwa Johna Humphreya wynika jednoznacznie, że René Cassin był raczej redaktorem dokumentu niż projektodawcą. Jego rola była decydująca w nadaniu Deklaracji odpowiedniej formy, a nie treści — ta bowiem była efektem pracy Departamentu Praw Człowieka Sekretariatu Generalnego i jego dyrektora.

W konsekwencji część autorów przedstawiających losy Deklaracji nie stroni od złośliwości pod adresem Cassina ${ }^{35}$, choć za najbardziej miarodajny należy uznać komentarz Hobbinsa, który stwierdził, że nie zamierza pomniejszać udziału Cassina, jako że jego całe życie poświęcone było prawom człowieka, i że „Cassin słusznie został uhonorowany Nagrodą Nobla za pracę na rzecz praw człowieka” ${ }^{36}$. Celem Hobbinsa było ,jedynie” wskazanie, kto jest właściwym twórcą pierwszego projektu Powszechnej deklaracji praw człowieka.

Proces powstawania Powszechnej deklaracji ma jeszcze kilku innych pomniejszych bohaterów, aczkolwiek ich rola była niewielka w porównaniu ze wspomnianymi postaciami. Warto wspomnieć m.in. o Jacques'u Maritainie, którego uważa się za jednego z ojców Deklaracji w wymiarze doktrynalnym, Hernanie Santa Cruz, gorącemu zwolennikowi włączenia do Deklaracji praw tzw. II generacji, czy Hansie Mehta z Indii, której prospołeczna, w tym prokobieca, aktywność widoczna była także w pracach Deklaracji (przypisuje się jej m.in. zmianę $\mathrm{w}$ artykule pierwszym frazy all men are na all human beings are).

\section{Typizacja: role twórców Powszechnej deklaracji}

Autorów Powszechnej deklaracji można zróżnicować, przypisując im określone role $\mathrm{w}$ trakcie przygotowywania, zmian i przyjęcia ostatecznego projektu przez Trzeci Komitet i Zgromadzenie Ogólne. Wskazać można m.in. role: a) inspiratora, b) patrona, c) kreatora, d) redaktora, e) strażnika, f) korektora.

Funkcja inspiratora polegała na zainicjowaniu prac i stworzeniu ogólnej koncepcji dokumentu. Rola inspiratora jest funkcją zwerbalizowanej potrzeby realizacji konkretnego projektu polityczno-prawnego. Za patrona należy uważać osobę, która sprawowała polityczną opiekę nad całym projektem, tzn. była odpowiedzialna za gromadzenie zaso-

${ }^{34}$ R. Cassin określał w późniejszych latach pracę Humphreya jako „doskonałą pracę dokumentacyjną”, a swoją rolę jako „główną odpowiedzialność za stworzenie pierwszego projektu”, cyt. za: M.A. Glendon, John P. Humphrey..., s. 255. Zob. także J. Winter, Dreams of Peace and Freedom: Utopian Moments in the Twentieth Century, Binghamton 2006, s. 99-120; J. Gray, Champions of Peace, London 1976; S. Waltz, op. cit., s. 441-442 oraz przypis 22 na s. 447; J. Morsink, op. cit., s. 29.

35 Alfred William Simpson napisał, że Cassin „nie był na pewno ojcem Deklaracji, a nawet jej matką”. A.W. Simpson, Human Rights and the End of Empire: Britain and the Genesis of the European Convention, New York 2001, s. 365. Krytycznie o przypisywaniu Cassinowi autorstwa Deklaracji również J. Morsink, op. cit., s. 29.

36 'Magna Carta of Mankind' uncovered at McGill, „The Reporter” 12, 1988, nr 7, http://humanrightsmuseum.ca/exhibits/jph/images/gallery/recognition_at_last/transcript_02.html (dostęp: 20.01.2016). 
bów politycznych umożliwiających proces przygotowania i wejścia w życie dokumentu. Kreator odpowiadał za opracowywanie treści projektu, był twórcą (w potocznym rozumieniu tego słowa) merytorycznej zawartości projektu. Różnicując funkcje kreatora i inspiratora, warto podkreślić, że o ile kreator miał wskazywać, „,co projekt ma zawierać”, o tyle inspirator odpowiadał na pytanie, „czym Deklaracja ma być”.

Funkcja redaktora polegała na wydatnym, dokonywanym w sposób nieincydentalny i systematyczny, uzupełnianiu i doskonaleniu projektu dokumentu pod względem zawartości merytorycznej i formy, niezmieniającym jednak w sposób zasadniczy wstępnej, zarysowanej wcześniej koncepcji (gdyby podmiot dokonujący redakcji zmienił koncepcję merytoryczną projektu, to należałoby go uznać za kreatora). Z kolei funkcję korektora charakteryzują niewielkie zmiany projektu, poprawiające konkretne postanowienia dokumentu bądź zwiększające prawdopodobieństwo akceptacji politycznej dla projektu. Tak więc rolą korektora było wskazywanie niedociągnięć projektu oraz wpływanie na poprawę/zmianę jednego lub kilku artykułów, a od redaktora odróżnia go sporadyczność i niesystematyczność działań.

Za strażnika należy uznać osobę, która sprawowała pieczę w toku debat nad projektem, jego spójnością, zachowaniem istotności dokumentu i terminowością (w tym zapobiegała obstrukcji). Rolą strażnika było także objaśnienie projektu danemu audytorium (np. członkom Komisji Praw Człowieka, Rady Gospodarczo-Społecznej, Trzeciego Komitetu), wykazywanie jego znaczenia i w tym sensie jego polityczna obrona.

Nie jest zasadne wskazywanie na to, która z ról była istotniejsza - dla sfinalizowania prac każda z nich była ważna, jeśli nie niezbędna, a bez osób je spełniających nie udałoby się Powszechnej deklaracji przyjąć 10 grudnia 1948 r. Przyjęta powyżej klasyfikacja ról umożliwia przyporządkowanie wskazanych we wcześniejszych akapitach rozdziału osobistości biorących udział w tworzeniu Deklaracji. Daną funkcję można oczywiście przypisać kilku osobom.

Na podstawie powyższej analizy można wskazać, że rolę patrona w procesie powstawania Powszechnej deklaracji pełniła bez wątpienia Eleanor Roosevelt. Była głównym organizatorem przedsięwzięcia, w publicznych dyskusjach i sporach broniła idei Deklaracji oraz kontaktowała się z politycznymi przywódcami.

Wśród inspiratorów wyróżnić można kilka osób. Spiritus movens Deklaracji była sama Roosevelt, ale nie należy zapominać też o Changu, Maliku, Maritainie. W wymiarze chronologicznym aktywność inspiratora i patrona przenikają się nawzajem, tzn. implementacja projektu powstawania dokumentu wymagała jednocześnie inicjatywy i ogólnego zarysu celu i znaczenia koncepcji Deklaracji (rola inspiratora) oraz utworzenia zaplecza politycznego i wsparcia powstania Deklaracji (rola patrona). Łącznikiem $\mathrm{w}$ roli patrona i inspiratora jest $\mathrm{w}$ pierwszej fazie prac Eleanor Roosevelt, jednakże należy zwrócić uwagę, że rozpoczęcie faktycznych prac nad Deklaracją jako dokumentem prawnomiędzynarodowym wyrugowało Roosevelt $\mathrm{z}$ roli inspiratora. W konsekwencji rosła rola Malika i Changa jako inspiratorów.

Kreatorem, w świetle dotychczasowej wiedzy, był przede wszystkim John Humphrey. To on w oparciu o prace dokumentacyjne opracował uniwersalny katalog praw i wolności, 
będący podstawą dalszych prac. Przedstawienie katalogu było wyrazem implementacji określonej koncepcji dokumentu i rolę Humphreya nie sposób zredukować do osoby tylko li przyjmującej instrukcje ze strony bardziej prominentnych Malika i Changa.

Funkcję redaktora pełnił przede wszystkim René Cassin. Jego rola z perspektywy akceptacji politycznej (tzn. ze strony państw członków poszczególnych organów ONZ lub ciał podporządkowanych Zgromadzeniu Ogólnemu) projektu dokumentu była nieoceniona. Nieuprawnione jest $z$ kolei przypisywanie Cassinowi roli kreatora ${ }^{37}$. Specyfiką prac nad Powszechną deklaracją było wyodrębnienie funkcji kreatora i redaktora. W sensie merytorycznym i technicznym obie funkcje mogłyby być realizowane przez tę samą osobę lub te same osoby (zadaniem kreatora może być także poprawienie i przygotowanie tekstu typowe dla roli redaktora). W wyniku perturbacji politycznych (a zapewne także chęci obstrukcji ze strony państw socjalistycznych i ambicji samego Cassina) doszło do zmian projektu, nienaruszających jednak jego jądra. $Z$ analizy podejmowanych przez Cassina prac wynika, że przyjęta przez niego rola wykracza poza redakcję i można zaryzykować twierdzenie, że w ten sposób stawał się on „minipatronem” projektu w pracach Komisji. $\mathrm{W}$ znacznie mniejszym stopniu rolę korektora można przypisać Malikowi, rewidującemu częściowo pierwszy i drugi projekt Deklaracji (głównie jej preambułę).

Za strażników należy uznać przede wszystkim dwóch reprezentantów Komisji: Malika oraz Cassina, $\mathrm{w}$ mniejszym stopniu Changa. Powyższa rola miała przede wszystkim charakter polityczny, ale efektywnym strażnikiem mógł być jedynie ktoś bardzo dobrze merytorycznie zapoznany z ideą i koncepcją Deklaracji. Wszystkie wymienione w roli strażnika osobistości spełniały powyższe kryterium.

Rolę korektora pełniło wiele osób. Jak już wspomniano, ich wkład jest na tyle mały, że nie należy uznawać ich za redaktorów. W trakcie prac legislacyjnych nad projektem Powszechnej deklaracji wielu przedstawicieli zgłosiło szereg mniej bądź bardziej istotnych uwag wpływających za ostateczną treść dokumentu. Zaznaczyć należy szczególnie rolę takich osób, jak Charles Malik (Liban), Peng-chun Chang (Chiny), Eleanor Roosevelt (USA), Hernan Santa Cruz (Chile), William Hodgson (Australia), Charles Dukes i Geoffrey Wilson (Wielka Brytania), Hansa Mehta (Indie), Omar Loutfi (Egipt), Carlos Romulo i Salvador Lopez (Filipiny), Carton Wiart (Belgia), Karim Azkoul (Liban), Aleksander Bogomołow $(\mathrm{ZSRR})^{38}$.

\section{Podsumowanie}

Poglądy i doświadczenia członków Komisji Praw Człowieka miały znaczenie przede wszystkim dla szerokiego poparcia dla uwzględnienia praw społeczno-kulturalnych w Deklaracji. Nie sposób ukryć zachodniej (w sensie cywilizacyjnym) proweniencji Deklaracji, jednak była ona modyfikowana przez aktywność osób pochodzących z innych

37 J. Morsink, choć krytykuje przypisywanie Cassinowi autorstwa projektu, określa go jako jednego z głównych architektów Deklaracji - J. Morsink, op. cit., s. 29-31 oraz 343.

38 Zob. także S. Waltz, op. cit., s. 443-446. 
kręgów kulturowych akcentujących rolę praw człowieka tzw. drugiej generacji. Wykazane w artykule typy ról ułatwiają przedstawienie wkładu poszczególnych osób w powstanie Powszechnej deklaracji praw człowieka. Zidentyfikowanie ich udziału pomaga wyjaśnić kontrowersje dotyczące powstania Deklaracji, szczególnie w kontekście przyznania Pokojowej Nagrody Nobla René Cassinowi. Podkreślenia wymaga kolektywność przedsięwzięcia i uznanie znaczącej roli Johna Humphreya w procesie powstawania Deklaracji.

\section{Bibliografia}

Bayefsky A.F., The UN Human Rights Treaty System, Kluwer Law International, Hague 2001.

Challenge of Human Rights: Charles Malik and the Universal Declaration, red. C.H. Malik, Charles Malik Foundation, Centre for Lebanese Studies, Oxford 2000.

Darraj S.M., Universal Declaration of Human Rights, Infobase Publishing, New York 2010.

Freedman R., The United Nations Human Rights Council. A Critique and Early Assessment, Routledge, New York 2013.

Glendon M.A., John P. Humphrey and the drafting of the Universal Declaration of Human Rights, „Journal of the History of International Law" 2000, nr 2, s. 250-260.

Glendon M.A., World Made New: Eleanor Roosevelt and the Universal Declaration of Human Rights, Random House, New York 2001.

Gray J., Champions of Peace, Paddington, London 1976.

Hermon E., The promotion of human rights: René Cassin's contribution to the promotion of peace, „Peace and Change" 16, 1991, nr 1, s. 3-21.

Hobbins A.J., René Cassin and the Daughter of Time: the first draft of the Universal Declaration of Human Rights, „Fontanus” 2, 1989, http://digitool.Library.McGill.CA:80/R/-?func=dbin-jump-full\&object_ id=19018\&silo_library=GEN01 (dostęp: 20.02.2016).

Hobbins A.J., Steward A., Bringing individual human rights issues to the United Nations: John Humphrey and the quest for compensation, „Canadian Yearbook of International Law” 41, 2003, s. 187-223.

Human Rights Thirty Years After the Universal Declaration, red. B. Ramcharan, Martinus Nijhoff, Boston 1979.

Humphrey J., Human Rights \& the United Nations: A Great Adventure, Dobbs Ferry, Transnational Publishers, New York 1984.

Humphrey J., The Universal Declaration of Human Rights: Its History, Impact, and Juridical Character, [w:] Human Rights Thirty Years After the Universal Declaration, red. B.G. Ramcharan, Martinus Nijhoff, Boston 1979.

Johnson G., Symonides J., Universal Declaration of Human Rights: A History of Its Creation and Implementation. 1948-1998, Unesco Pub., Paris 1998.

Krumbein F., P.C. Chang - Chinese father of human rights, „Journal of Human Rights” 15, 2014, s. 332-352.

McFarland S., The Universal Declaration of Human Rights: A tribute to its architects, „Public Integrity” 19, 2017, s. 108-122.

'Magna Carta of Mankind' uncovered at McGill, „The Reporter” 12, 1988, nr 7, http://humanrightsmuseum. ca/exhibits/jph/images/gallery/recognition_at_last/transcript_02.html (dostęp: 20.01.2016).

Mitoma G., Charles H. Malik and human rights: notes on a biography, „Personal Narrative \& Political Discourse" 33, 2010, s. 222-223.

Morsink J., Philosophy of the Universal Declaration, „Human Rights Quarterly” 6, 1984, nr 3, s. 309-334.

Morsink J., Universal Declaration of Human Rights. Origins, Drafting, and Intent, Pennsylvania University Press, Philadelphia 1999. 
Munro B., The Universal Declaration of Human Rights. Maritain and the Universality of Human Rights, [w:] Philosophical Theory and the Universal Declaration of Human Rights, red. W. Sweet, Ottawa University

Press, Ottawa 2003, s. 109-126.

Roosevelt E., The Autobiography of Eleanor Roosevelt, Da Capo Press, New York 1992.

Roosevelt E., Human rights and human freedom: The American perspective, „New York Times Magazine” 24 marca 1946, s. 21.

Roosevelt E., On My Own, Harper Brothers, New York 1958.

Roosevelt F.D., The Economic Bill of Rights, [w:] The Public Papers \& Addresses of Franklin D. Roosevelt, t. 13, red. S. Rosenman, Harper, New York 1950.

Sears J., Eleanor Roosevelt and the Universal Declaration of Human Rights, http://www.fdrlibrary.marist. edu/library/pdfs/sears.pdf (dostęp: 20.02.2016), s. 1-11.

Simpson A.W., Human Rights and the End of Empire: Britain and the Genesis of the European Convention, Oxford University Press, New York 2001.

Tolley H., The U. N. Commission on Human Rights, Westview Press, Boulder-London 1987.

The Universal Declaration of Human Rights. A Common Standard of Achievement, red. G. Alfredsson, A. Eide, Martinus Nijhoff Publishers, Hague 1999.

Vatter M., Politico-theological foundations of the universal human rights: The case of Maritain, „Social Research" 80, 2013, nr 1, s. 233-257.

Waltz S., Reclaiming and rebuilding the history of the Universal Declaration of Human Rights, „Third World Quarterly" 23, 2002, nr 3, s. 437-448.

Winter J., Dreams of Peace and Freedom: Utopian Moments in the Twentieth Century, Vail-Ballou Press, Binghamton 2006, s. 99-120.

\section{The creation of the Universal Declaration of Human Rights. Disputes on authorship and roles of individuals concerning preparation and adopting of the Declaration}

Keywords: protection of human rights, the Universal Declaration of Human Rights, the creators of the UDHR, the United Nations Commission on Human Rights

\section{Summary}

The Universal Declaration of Human Right was prepared, revised and finally adopted by many representatives to the United Nations bodies. The study presents the drafting of the Declaration from the perspective of people whose contribution was the most essential. They were members of the Commission of Human Rights and its drafting committee (Eleanor Roosevelt, Peng-chun Chang, Charles Malik, René Cassin), the UN Secretariat (John P. Humphrey). All of them can be labeled as the authors of the Declaration which seems to be an unnecessary generalisation. The underestimated role of Humphrey and overestimated role of Cassin are presented in detail. The paper concludes that the contribution to the Universal Declaration of Human Rights may be differentiated. Ultimately, the author argues that roles of a sponsor, an initiator, a creator, a redactor, a guard and a reviser can be distinguished. 